\title{
PENGARUH KOMUNIKASI DAN LINGKUNGAN KERJA TERHADAP KINERJA KARYAWAN PT PLN (PERSERO) CABANG BANJARMASIN
}

\section{Junaidi}

Fakultas Ekonomi Uniska Banjarmasin Jl. Adhyaksa No. 2 Kayu Tangi Banjarmasin Kalimantan Selatan e-mail: junaidi_manda@ymail.com

\begin{abstract}
This research is aimed to examine the effect of communication and work environment on employee performance. Popolasi research is employees of PT.PLN (Persero) Branch Banjarmasin with a large sample taken as many as 135 samples and data nalisis done using SPSS program version 21.00. The result of hypothesis analysis and test show that there is influence of communication and work environment to employee performance PT.PLN (Persero) Branch Banjarmasin. Hypothesisl (H1): There is a positive and significant effect of partial communication on employee performance PT.PLN (Persero) Branch Banjarmasin. Hypothesis2 (H2): There is a positive influence and partially significant work environment on employee performance PT.PLN (Persero) Branch Banjarmasin. Hypothesis 3 (H3): There is a positive and significant influence simultaneously communication, motivation and work environment on employee performance PT.PLN (Persero) Branch Banjarmasin.
\end{abstract}

Keywords: Communication, Work Environment, and Employee Performance

\begin{abstract}
Abstrak
Penelitian ini ditujukan untuk menguji pengaruh komunikasi dan Lingkungan kerja terhadap kinerja karyawan. Popolasi penelitian adalah karyawan PT.PLN (Persero) Cabang Banjarmasin dengan besar sampel yang diambil sebanyak 135 sampel dan nalisis data dilakukan menggunakan program SPSS versi 21.00. Hasil analisis dan pengujian hipotesis menunjukkan terdapat pengaruh komunikasi dan lingkungan kerja terhadap kinerja karyawan PT.PLN (Persero) Cabang Banjarmasin. Hipotesis 1 (H1) : terdapat pengaruh yang positif dan signifikan komunikasi secara parsial terhadap kinerja karyawan PT.PLN (Persero) Cabang Banjarmasin. Hipotesis2 (H2) : terdapat pengaruh positif dan signifikan secara parsial lingkungan kerja terhadap kinerja karyawan PT.PLN (Persero) Cabang Banjarmasin. Hipotesis 3 (H3) : terdapat pengaruh positif dan signifikan secara simultan komunikasi, motivasi dan lingkungan kerja terhadap kinerja karyawan PT.PLN (Persero) Cabang Banjarmasin
\end{abstract}

Kata kunci: Komunikasi, Lingkungan Kerja, dan Kinerja Karyawan 


\section{PENDAHULUAN}

Dalam mempertahankan dan meningkatkan sumber daya manusia yang berkualitas, untuk menujang tercapainya tujuan, PT. PLN (Persero) Cabang Banjarmasin memiliki devisi sumber daya manusia yang fokus dalam bidangnya. Devisi sumber daya manusia bertujuan membentuk, mempertahankan dan meningkatkan kualitas karyawan, serta diharapkan mampu menciptakan hubungan yang harmonis dilingkungan kerja perusahaan. Lingkungan perusahaan adalah ruang lingkup tempat karyawan bekerja, disinilah terjadinya interaksi, hubungan komunikasi baik antara karyawan maupun antara atasan dan bawahan ataupun sebaliknya. Komunikasi tidak hanya penting untuk manusia tetapi juga penting dalam sistem pengendalian manajemen yang merupakan alat untuk mengarahkan, memotivasi, memonitor atau mengamati serta evaluasi pelaksanaan manajemen. Dan sebagai pihak manajemen perusahaan akan mengarahkan sumber daya manusia yang dimilikinya pada tujuan perusahaan sehingga kinerja yang dilakukan dapat berjalan lebih efesien dan lancar, yang dimonitor atau yang diatur dalam sistem pengendalian manajemen. Kinerja karyawan yang mempunyai kualitas merupakan suatu tujuan dalam mendukung tercapainya visi dan misi serta tujuan dalam tumbuh kembangnya dimasa akan datang. Menurut Hasibuan (2001:10) manajemen sumber daya manusia adalah “ Ilmu dan seni mengatur hubungan dan peranan tenaga kerja agar efektif dan efisien, membantu terwujudnya tujuan perusahaan, karyawan dan masyarakat. Hubungan yang terjadi dilingkungan perusahaan serta peranan sumber daya manusia yang mendukung akan sangat membantu dalam pencapaian tujuan.

Dalam pengelolaan sumber daya manusia manajemen perusahaan dituntut mampu untuk membentuk kualitas karyawan yang handal, melalui penciptaan komunikasi yang harmonis dalam perusahaan, menumbuhkan motivasi diri karyawan serta dididukung lingkungan kerja yang baik akan menciptakan kondisi kinerja karyawan semakian meningkat.

Proses komunikasi yang terjadi di dalam perusahaan khususnya yang menyangkut komunikasi antara pimpinan dan karyawan merupakan faktor penting dalam menciptakan suatu organisasi yang efektif. Komunikasi efektif tergantung dari hubungan karyawan yang memuaskan yang dibangun berdasarkan iklim dan kepercayaan atau suasana organisasi yang positif. Hubungan atasan dan bawahan merupakan jantung pengelolaan yang efektif. Agar hubungan ini berhasil, harus ada kepercayaan dan keterbukaan antara atasan dan bawahan. (Muhammad, 2001: 172)..

Untuk mewujudkan sumber daya manusia yang berkualitas yang mempunyai keunggulan-keunggulan mengharuskan perusahaan untuk menemukan cara terbaik dalam mensosialisasikan, pendayagunaan, pembinaan serta mengkaryakan karyawannya dalam melakukan fungsinya demi tercapainya pembentukan kinerja karyawan yang handal. Karyawan yang mempunyai kemauan lebih akan terdorong untuk berbuat semaksimal mungkin dalam melaksanakan tugasnya karena meyakini bahwa dengan keberhasilan organisasi dalam mencapai tujuan dan berbagai sasarannya, kepentingan-kepentingan pribadi para karyawan tersebut akan tercakup pula seiring tujuan yang dicapai perusahaan.

PT.PLN (Persero) Cabang Banjarmasin merupakan perusahaan BUMN yang bergerak dalam pelayanan kelistrikan untuk memenuhi kebutuhan listrik masyarakat di wilayah banjarmasin pada khususnya. Dalam pengelolaan sumber daya manusia PT.PLN 
(Persero) Cabang Banjarmasin berupaya semaksimal mungkin untuk menciptakan kinerja yang berkualitas melalui Devisi Sumber Daya Manusia yang fokus dibidangnya, bergerak dalam membentuk, meningkatkan serta mempertahankan kualitas sumber daya manusia yang handal, dalam mendukung tercapainya visi dan misi serta tujuan perusahaan.

Adapun visi dan misi serta tujuan tersebut : Visi adalah Diakui sebagai pengelola ketenagalistrikan yang efisien, handal dan berkualitas di wilayah Indonesia Timur dengan mengedepankan kearifan lokal. Dan Misi adalah (1) menjalankan bisnis ketenaga listrikan yang berorientasi kepada kepuasan pelanggan, anggota perusahaan dan kontribusi yang optimal kepada Perseroan; (2) Menjadikan listrik sebagai media untuk meningkatkan kualitas kehidupan masyarakat dan mendorong pertumbuhan ekonomi; (3) Meningkatkan kinerja organisasi secara berkelanjutan serta mengutamakan keselamatan kerja yang berwawasan lingkungan;

Mengembangkan SDM yang berbudaya kerja unggul melalui high trust society. Serta Tujuannya adalah menyelenggarakan usaha penyediaan tenaga listrik bagi kepentingan umum dengan jumlah dan mutu yang memadai, serta melaksanakan penugasan pemerintah dibidang ketenaga listrikan yang menunjang pembangunan di Provinsi Kalimantan Selatan dan Kalimantan Tengah.

Salah satu misi PT.PLN (Persero) Cabang Banjarmasin yang tertuang dalam poin ke empat, jelas bahwa devisi sumber daya manusia dituntut bekerja keras untuk mewujudkan misi tersebut. Pencapaian kualitas kerja yang tinggi dalam pengelolaan sumber daya manusia. yang handal, baik dalam pengelolaan manajemen maupun dalam pelayanan terhadap masyarakat sering kali terjadi mengalami hambatan. Ini terlihat seiring kualitas kerja karyawan yang sering kali menumbuhkan kritikan masyarakat terhadap kinerja karyawan melalui media cetak (Koran), internet dan sebagainya.

Seperti yang diberitakan Banjarmasinpost.Co.Id, Banjarmasin, pemadaman listrik yang terjadi pada hari selasa tanggal 18 Januari 2014 pukul 11.28 wita terjadi gangguan pada jaringan transmisi 70 kV jalur Trisakti - Ulin line $1 \& 2$. Dalam proses penormalan sistem terjadi gangguan kedua pada Rabu, 29 Januari 2014 pukul 01.20 WITA yaitu putusnya sambungan transmisi line 1 Gardu Induk Seberang Barito arah Trisakti. Dan selanjutnya Hari Jumat tanggal 6 Mei 2014 Pemadaman listrik selama 12 Jam di beberapa kawasan Banjarmasin Timur) disebabkan meledaknya lemari kubikal busbar atau tempat menyimpan rel pembagi tegangan. Manager PT PLN Kalselteng Area Banjarmasin Rayon A Yani, Winardi menjelaskan, penyebab terjadinya ledakan dikarenakan sambungan konektor di busbar tersebut lost contact.

Terkait hal tersebut, secara nasional dalam pemberitaan TRIBUN-MEDAN.com. SIANTAR Dalam daftar keluhan konsumen nasional, pelayanan mengenai ketenaga listrikan berada di posisi ke-empat teratas di bawah perbankan, perumahan, dan telekomunikasi (multimedia). Hal tersebut diketahui dalam acara sosialisasi yang diadakan Perusahaan Listrik Negara (PLN), Hari Senin tanggal 21 April 2014, di Hotel Sapadia. Dalam sosialisasi berjudul peningkatan pemahaman masyarakat dalam pemakaian dan pemanfaatan tenaga listrik, layanan di bidang ketenagalistrikan menerima 11,3 persen suara keluhan dari pengaduan masyarakat. Listrik berada di atas air PAM, transportasi, dan leasing (Winsisma Wansyah, salah seorang pegawai di Direktorat Jenderal Ketenagalistrikan Kementerian Energi dan Sumberdaya 
Mineral (ESDM)). Menyatakan beberapa keluhan konsumen terbanyak yang sering disampaikan konsumen terkait ketenagalistrikan, antara lain adalah pemadaman yang terlalu sering, layanan petugas yang kurang simpatik, tarif dasar listrik yang terlalu tinggi, dan penerangan jalan umum yang tidak sesuai. Bahkan, dari daftar urutan kemudahan memperoleh listrik di negara-negara Asean, Indonesia berada di posisi sembilan.

\section{TINJAUAN PUSTAKA}

Menurut Effendy (2000). komunikasi adalah proses penyampaian pikiran atau perasaan oleh seseorang kepada orang lain dengan menggunakan lambang-lambang yang bermakna bagi kedua pihak dalam situasi yang tertentu komunikasi menggunakan media tertentu untuk merubah sikap atau tingkah laku seorang atau sejumlah orang sehingga ada efek tertentu yang diharapkan. Sedangkan menurut Handoko (2002). Komunikasi adalah proses pemindahan pengertian dalam bentuk gagasan, informasi dari seseorang ke orang lain. Selanjutnya menurut Robbins (2002) tidak ada kelompok yang dapat eksis tanpa komunikasi : pentransferan makna di antara anggota-anggotanya. Hanya lewat pentransferan makna dari satu orang ke orang lain informasi dan gagasan dapat dihantarkan. Tetapi komunikasi itu lebih dari sekedar menanamkan makna tetapi harus juga dipahami

Fungsi komunikasi adalah :

a. Kendali : komunikasi bertindak untuk mengendalikan prilaku anggota dalam beberapa cara, setiap organisasi mempunyai wewenang dan garis panduan formal yang harus dipatuhi oleh karyawan.

b. Motivasi : komunikasi membantu perkembangan motivasi dengan menjelaskan kepada para karyawan apa yang harus dilakukan bagaimana mereka bekerja baik dan apa yang dapat dikerjakan untuk memperbaiki kinerja jika itu di bawah standar.

c. Pengungkapan emosional : bagi banyak karyawan kelompok kerja mereka merupakan sumber utama untuk interaksi sosial, komunikasi yang terjadi di dalam kelompok itu merupakan mekanisme fundamental dengan mana anggotaanggota menunjukkan kekecewaan dan rasa puas mereka oleh karena itu komunikasi menyiarkan ungkapan emosional dari perasaan dan pemenuhan kebutuhan sosial.

d. Informasi : komunikasi memberikan informasi yang diperlukan individu dan kelompok untuk mengambil keputusan dengan meneruskan data guna mengenai dan menilai pilihan-pilihan alternatif (Robbins, 2002 : 310-311).

Sedangkan Bentuk-bentuk komunikasi dapat dijabarkan sebagai berikut :

a. Komunikasi vertikal Komunikasi vertikal adalah komunikasi dari atas ke bawah dan dari bawah ke atas atau komunikasi dari pimpinan ke bawahan dan dari bawahan ke pimpinan secara timbal balik.

b. Komunikasi horisontal Komunikasi horisontal adalah komunikasi secara mendatar, misalnya komunikasi antara karyawan dengan karyawan dan komunikasi ini sering kali berlangsung tidak formal yang berlainan dengan komunikasi vertikal yang terjadi secara formal.

c. Komunikasi diagonal Komunikasi diagonal yang sering juga dinamakan komunikasi silang yaitu seseorang dengan orang lain yang satu dengan yang lainnya berbeda dalam kedudukan dan bagian (Effendy, 2000 : 17). 
Pendapat lainnya menyebutkan, komunikasi dapat mengalir secara vertikal atau lateral (menyisi). Dimensi vertikal dapat dibagi menjadi ke bawah dan ke atas.

a. Ke bawah : Komunikasi yang mengalir dari satu tingkat dalam suatu kelompok atau organisasi ke suatu tingkat yang lebih bawah. Kegunaan dari pada komunikasi ini memberikan penetapan tujuan, memberikan instruksi pekerjaan, menginformasikan kebijakan dan prosedur pada bawahan, menunjukkan masalah yang memerlukan perhatian dan mengemukakan umpan balik terhadap kinerja.

b. Ke atas : komunikasi yang mengalir ke suatu tingkat yang lebih tinggi dalam kelompok atau organisasi digunakan untuk memberikan umpan balik kepada atasan, menginformasikan mereka mengenai kemajuan ke arah tujuan dan meneruskan masalah-masalah yang ada. Sedangkan dimensi lateral, komunikasi yang terjadi di antara kelompok kerja yang sama, diantara anggota kelompokkelompok kerja pada tingkat yang sama, diantara manajer-manajer pada tingkat yang sama (Robbins, 2002).

Sedangkan menurut Joseph De Vito, Komunikasi interpersonal dapat diartikan "is the communication that takes place between two person who have an established relationships; (De Vito, 2004: 4). Sementara menurut Verdeber (1986) mengemukakan bahwa komunikasi interpersonal merupakan suatu proses interaksi dan pembagian makna yang terkandung dalam gagasan-gagasan dan perasaan (Alo Liliweri : 1994). Komunikasi interpersonal merupakan proses pengiriman dan penerimaan pesan di antara dua orang atau di antara sekelompok kecil orang, dengan berbagai efek dan umpan balik. (Sendjaya; 1994). Dapat disimpulkan bahwa komunikasi interpersonal merupakan proses pengiriman pesan antara dua orang atau lebih, dengan efek dan feedback langsung. Komunikasi interpersonal juga merupakan suatu pertukaran, yaitu tindakan menyampaikan dan menerima pesan secara timbal balik. Makna, sesuatu yang dipertukarkan dalam proses tersebut. Makna adalah kesamaan pemahaman di antara orang - orang yang berkomunikasi terhadap pesanpesan yang digunakan dalam proses komunikasi. Komunikasi interpersonal memiliki sifat-sifat (1) bersifat dua arah yang berarti melibatkan dua orang dalam situasi interaksi, ada unsur dialogis dan (2) ditujukan kepada sasaran terbatas dan dikenal.

Seperti apa yang dikemukakan oleh Judy C. Person (1983). Komunikasi interpersonal bersifat transaksional; tindakan pihak-pihak yang berkomunikasi secara serempak dalam menyampaikan dan menerima pesan. Komunikasi interpersonal merupakan rangkaian tindakan, kejadian dan kegiatan yang terjadi secara terus-menerus. Komunikasi interpersonal bukan sesuatu yang statis tetapi bersifat dinamis. Artinya, segala yang tercakup dalam komunikasi interpersonal selalu dalam keadaan berubah baik pelaku komunikasi, pesan, situasi, maupun lingkungannya. Komunikasi Interpersonal juga menyangkut aspek-aspek isi pesan dan hubungan antar pribadi, melibatkan dengan siapa kita berkomunikasi dan bagaimana hubungan dengan partner.

Dalam komunikasi interpersonal dilakukan pemahaman komunikasi dan hubungan interpersonal dari sudut individu, yang selanjutnya disebut dengan proses psikologis. Proses psikologis merupakan bagian penting dalam komunikasi interpersonal, karena dalam komunikasi interpersonal individu mencoba menginterpretasikan makna yang menyangkut diri sendiri, diri orang lain dan 
hubungan yang terjadi. Proses psikologis dapat berpengaruh pada komunikasi dan hubungan interpersonal, karena individuindividu menggunakan sebagai pedoman untuk bertindak dan berperilaku.

Dalam komunikasi interpersonal, terjadi komunikasi konvergen. Komunikasi konvergen merupakan proses mencipta dan saling berbagi informasi mengenai realita di antara dua partisipan komunikasi atau lebih agar dapat dicapai saling pengertian dan kesepakatan makna (meaning) antara satu dengan yang lain. Komunikasi melibatkan realitas fisik maupun psikologis dalam menanggapi sebuah informasi. Masingmasing pihak akan melakukan perceiving (pencerapan), lalu menginterpretasikan informasi tersebut sehingga terjadi understanding (pemahaman) dan selanjutnya timbul believing (keyakinan) yang menimbulkan action atau tindakan. Adanya kesamaan tindakan A \& $\mathrm{B}$ akan menghasilkan tindakan kolektif.

Menurut Kincaid's Convergence Model, komunikasi didefinisikan sebagai "Process in which participants create and share information with one another in order to reach a mutual understanding". Tujuan utama komunikasi yang bersifat konvergen adalah mendekatkan pengertian masing-masing ke dalam suatu pengertian yang relatif sama antara patisipan yang satu dengan yang lain. Konvergen adalah kecenderungan dua atau lebih individu untuk bergerak menuju satu tujuan.

Konvergensi juga ditentukan oleh intensitas komunikasi di antara pimpinan dan karyawan atau antara atasan dan bawahan. Semakin sering terjadi komunikasi interpersonal akan semakin kuat ke arah kecenderungan konvergensi. Komunikasi yang berakhir dengan konvergensi akan memiliki pengaruh terhadap perilaku bawahan khususnya perilaku karyawan dalam bekerja. Semakin tinggi terjadinya intensitas konvergensi di mana pimpinan dan karyawan membentuk ke arah saling pengertian maka persetujuan dan kerja sama akan semakin baik.

a. Model Komunikasi Interpersonal

De Vito mengemukakan bahwa komunikasi tidak terjadi secara linier atau satu arah melainkan berkesinambungan. Akan terjadi pergantian peran dan fungsi antara sumber dan penerima. Setelah pesan sampai ke penerima, maka penerima akan memberi tanggapan atau umpan balik. Umpan balik yang telah disampaikan kepada pihak yang semula menjadi sumber pesan, menempatkan pihak yang semula pada posisi penerima pesan menjadi sumber.

Sumber Penerima : sumber penerima sebagai satu kesatuan yang tak terpisahkan untuk menegaskan bahwa setiap orang yang terlibat dalam komunikasi adalah sumber dan sekaligus penerima. Komunikasi ini melibatkan dua orang atau lebih dalam situasi interaksi. Situasi komunikasi interpersonal menuntut kedua belah pihak yang dalam hal ini adalah pimpinan dan karyawan untuk sama-sama aktif dalam proses komunikasi

Dalam Komunikasi interpersonal, dikenal istilah kompetensi. Kompetensi mengacu pada kemampuan untuk berkomunikasi secara efektif (Spitzberg dan Cupach,1989). Kompetensi mencakup halhal seperti pengetahuan tentang peran lingkungan (konteks) dalam mempengaruhi kandungan (content) dan bentuk pesan komunikasi. Istilah kompetensi juga berhubungan dengan kemampuan berbahasa dan kemampuan mengenai peraturanperaturan untuk interaksi komunikasi. Proses komunikasi antara pimpinan dengan karyawan di dalam organisasi menyangkut kemampuan komunikasi baik verbal maupun non verbal. Selain itu, kompetensi juga 
berkaitan dengan kemampuan individu untuk menumbuhkan kondisi adanya keterbukaan, empati, kepositifan, dukungan dan kesamaan.

Encoding dan Decoding: Mengacu pada tindakan memproduksi pesan. Dalam komunikasi interpersonal, fungsi encoding dan decoding terjadi pada kedua belah pihak yang berkomunikasi. Komunikasi bersifat dialogis.

Lingkungan kerja sangatlah perlu untuk diperhatikan karena merupakan salah satu faktor yang penting dalam menentukan kinerja karyawan. Dengan lingkungan kerja yang baik, para karyawan dapat terpacu untuk melaksanakannua dengan baik. Mereka akan merasa lebih senang dan lebih mudah untuk berkonsentrasi dalam bekerja sehingga kinerjanya tinggi. Sedangkan jika lingkungan kerja buruk, dapat berdampak buruk juga pada kinerja para karyawan. Hal ini dikarenakan mereka merasa tidak nyaman dalam bekerja sehingga kinerja menjadi rendah. Lingkungan kerja adalah sesuatu dari lingkungan pekerjaan yang memudahkan atau menyulitkan pekerjaan. Menyenangkan atau menyulitkan mereka termasuk di dalamnya adalah faktor penerangan, suhu udara, ventilasi, kursi dan meja tulis (Horbert N. Casson, 2006). Pendapat ini mengemukakan bahwa lingkungan kerja adalah segala sesuatu yang mencakup pelataran, bangunan kantor dan tata ruang kantor atau yang disebut kondisi atau lingkungan fisik serta kondisi jasmaniah tempat kerja (Komaruddin, 2005).

Dari definisi di atas menunjukkan bahwa untuk lingkungan kerja yang berbeda dalam lingkungan kerja memberi pengaruh yang besar pada setiap pekerjaan karyawan. Terdapat dua jenis lingkungan kerja yaitu lingkungan kerja fisik dan lingkungan kerja non fisik. Menurut Sarwoto (2007), lingkungan kerja fisik merupakan lingkungan atau kondisi tempat kerja yang dapat mempengaruhi atau meningkatkan efesiensi kerja, di antaranya adalah:

a. Tata ruang kerja yang tepat

b. Cahaya dalam ruangan yang tepat

c. Suhu dan kelembapan udara yang tepat

d. Suara yang tidak mengganggu konsentrasi kerja

Menurut Moekijat (2005), lingkungan kerja non fisik adalah segala sesuatu yang berhubungan dan mempunyai kekuatan serta mempunyai pengaruh terhadap jiwa karyawan, meliputi :

a. Suasana kerja dalam perusahaan

Suasana dalam perusahaan merupakan pendukung dalam kelancaran pekerjaan perusahaan. Dengan suasana kerja yang baik dapat menimbulkan semangat kerja karyawan. Suasana dalam perusahaan yang baik dapat dilihat dari hubungan antara atasan dengan bawahan atau sebaliknya. Dengan adanya hubungan yang baik, maka dapat menimbulkan saling pengertian antara pimpinan dengan karyawan serta dapat menumbuhkan motivasi kerja karyawan itu sendiri.

b. Keamanan kerja karyawan

Rasa aman akan menimbulkan ketenangan, dan ketenangan itu akan mendorong motivasi kerja karyawan sehingga kinerja menjadi baik. Rasa aman di sini meliputi diri pribadi maupun luar pribadi. Kaitan dengan diri pribadi adalah menyangkut keselamatan selama bekerja dan terjaminnya karyawan dalam memperoleh pekerjaan dan jabatan dalam perusahaan, selama ia melaksanakan tugasnya dengan prestasi kerja yang memuaskan. Sedangkan rasa aman dari luar pribadi adalah terjaminnya milik karyawan dari adanya perusakan dan pencurian.

Menurut Nitisemito

(2000:183), lingkungan kerja adalah segala sesuatu yang ada disekitar para pekerja yang dapat 
mempengaruhi dirinya dalam menjalankan tugas-tugas yang diembankan Definisi mengenai lingkungan kerja juga dikemukakan oleh Sedarmayanti (2001:1) lingkungan kerja adalah keseluruhan alat perkakas dan bahan yang dihadapi, lingkungan sekitarnya dimana seseorang bekerja, metode kerjanya, serta pengaturan kerjanya baik sebagai perseorangan maupun sebagai kelompok dapat ditarik kesimpulannya bahwa kondisi lingkungan kerja baik akan menunjang produktivitas karyawan yang pada akhirnya berdampak pada kenaikan tingkat kinerja karyawan.

Swastha dan Sukotjo (2004:26-27) menyatakan lingkungan perusahaan dapat diartikan sebagai keseluruhan dari faktorfaktor ekstern yang mempengaruhi baik organisasi maupun kegiatannya. Sedangkan arti lingkungan kerja secara luas mencakup semua faktor-faktor ekstern yang mempengaruhi individu, perusahaan, dan masyarakat. Sedangkan Heijrachman dan Husnan (1997:34) menyatakan bahwa yang dimaksud dengan pengaturan lingkungan kerja adalah pengaturan penerangan tempat kerja, pengontrolan terhadap suara gaduh, pengontrolan terhadap udara, pengaturan kebersihan tempat kerja, dan pengaturan tentang keamanan kerja.

Menurut Sedarmayanti (2001:21), lingkungan kerja fisik adalah semua keadaan berbentuk fisik yang terdapat di sekitar tempat kerja yang dapat mempengaruhi karyawan baik secara langsung maupun secara tidak langsung. Lingkungan kerja fisik adalah sesuatu yang berada di sekitar para pekerja yang meliputi cahaya, warna, udara, suara, serta musik yang mempengaruhi dirinya dalam menjalankan tugas- tugas yang dibebankan

Sedangkan menurut Nitisemito (2000:171) perusahaan hendaknya dapat mencerminkan kondisi yang mendukung kerja sama antara tingkat atasan, bawahan, maupun yang memiliki status jabatan yang sama di perusahaan. Kondisi yang hendaknya diciptakan adalah suasana kekeluargaan, komunikasi yang baik dan pengendalian diri.

Dari pendapat para ahli di atas dapat disimpulkan bahwa yang dimaksud dengan lingkungan kerja adalah keadaan di dalam tempat bekerja yang mencerminkan hubungan antara atasan dengan bawahan sehingga menciptakan suasana yang baik dan komunikasi yang baik juga dalam menjalankan tugas-tugasnya atau pekerjaannya. Jika lingkungan kerja menyenangkan, maka karyawan akan bekerja dengan bergairah dan lebih serius. Untuk menciptakan iklim yang menyenangkan perlu adanya pengaturan dan pengontrolan lingkungan kerja antara lain:

a. Pengaturan penerangan tempat kerja

b. Pengontrolan terhadap suara-suara gaduh

c. Pengontrolan terhadap udara, pengontrolan terhadap kebersihan tempat kerja

d. Pengontrolan keamanan tempat kerja.

Penciptaan lingkungan kerja yang menyenangkan dan dapat memenuhi kebutuhan pegawai akan memberikan rasa puas dan mendorong semangat kerja sehingga kinerja karyawan menjadi meningkat.

Kinerja karyawan merupakan suatu tolak ukur untuk menunjukkan perkembangan perusahan yang semuanya itu dapat dilihat dari pencapaian kinerja individu dalam melaksanakan tugas yang telah dibebankan baik oleh organisasi, instansi ataupun perusahaan. Dan tanpa disadari kinerja merupakan suatu beban yang harus dilaksanakan karyawan dalam kelangsungan tumbuh kembangnya perusahaan, serta dalam keseharian untuk peningkatan baik pelayanan maupun kelancaran dalam administrasi sesuai dengan apa yang ingin dicapai. 
Kinerja adalah hasil kerja yang dapat dicapai oleh seseorang atau sekelompok orang dalam suatu organisasi sesuai wewenang dan tanggung jawab masing-masing, dalam rangka upaya mencapai tujuan organisasi bersangkutan secara legal, tidak melanggar hukum dan sesuai dengan moral dan etika (Prawirosentono,2000:123).

Kinerja karyawan lebih mengarah pada tingkatan prestasi kerja karyawan (Jakson dalam Thoha,2005:87)

Untuk mengukur kinerja secara individual, McKenna dan Beech (1995) ada beberapa indikator, indikator-indikator dari kinerja yang sering dipergunakan untuk menilai kinerja individu pegawai menurut McKenna dan Beech adalah: Pengetahuan, kemampuan dan keterampilan pada pekerjaan/kompeten Sikap kerja, diekspresikan sebagai antusiasme, komitmen dan motivasi Kualitas pekerjaan Interaksi, misalnya keterampilan komunikasi dan kemampuan untuk berhubungan dengan orang lain dalam satu tim.

Untuk mengetahui pengaruh komunikasi dan motivasi terhadap kinerja karyawan maka dibuatlah suatu kerangka pemikiran. Komunikasi dan motivasi variabel bebas (variabel independen), sedangkan kinerja karyawan adalah variabel terikat (variabel dependen), maka hubungan antara variabel variabel bebas dan variabel terikat dalam penelitian ini digambarkan dalam sebuah kerangka konseptual penelitian sebagaimana terlihat pada gambar 1 berikut:

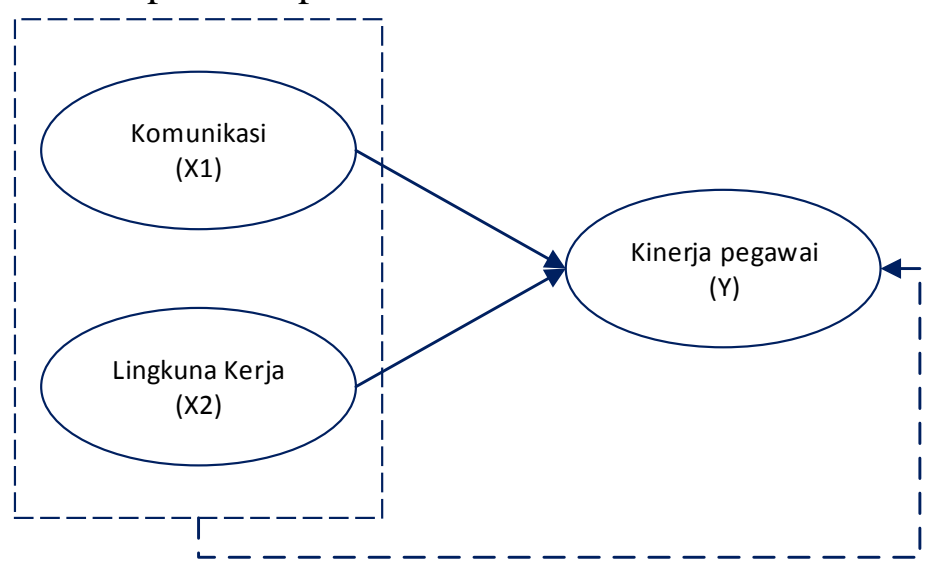

Hubungan Variabel Komunikasi dan Lingkungan Kerja Terhadap Kinerja Karyawan.

Berdasarkan kerangka penelitian tersebut, maka hipotesis sebagaiberikut:

H1 = Komunikasi berpengaruh terhadap kinerja karyawan PT. PLN Cabang Banjarmasin

H2 = Lingkungan kerja berpengaruh terhadap kinerja karyawan PT. PLN Cabang Banjarmasin

H3 = Komunikasi dan Lingkungan kerja berpengaruh secara simultan terhadap kinerja karyawan PT. PLN Cabang Banjarmasin

\section{METODE PENELITIAN}

Penelitian ini menggunakan jenis penelitian deskriptif analisis dengan pendekatan kuantitatif menggunakan studi satu tahap dimana data dikumpulkan sekaligus dalam satu tahap kegiatan.
Penelitian dilakukan di Banjarmasin pada perusahaan PT. PLN Cabang Banjarmasin.

Dalam memperoleh data yang berhubungan dengan penelitian isi kuesioner yang dibagikan kepada karyawan PT. PLN Cabang Banjarmasin terdiri dari : 
a. Identitas responden, yaitu mengenai nama, jenis kelamin, usia, pendidikan dan bagian (jabatan pekerjaan).

b. Pertanyaan mengenai tanggapan responden terhadap variabel: Komunikasi dan Motivasi terhadap Kinerja Karyawan.

Analisis data yang dipergunakan dalam penelitian ini adalah regresi linier berganda.

Dimana dalam penelitian ini terdapat tiga variabel independen yaitu Komunikasi, dan Motivasi. Persamaan regresi tersebut adalah sebagai berikut (Sugiyono :2012) :

$$
\hat{\mathbf{Y}}=\mathbf{a}+\mathbf{b}_{1} \mathbf{X}_{1}+\mathbf{b}_{2} \mathbf{X}_{2}+
$$

Keterangan :

$\begin{array}{ll}\mathrm{Y} & : \text { Kinerja Karyawan } \\ \mathrm{a} & : \text { Konstanta } \\ b_{1}, b_{2} & : \text { Koefisien regresi } \\ X_{1} & : \text { Komunikasi } \\ X_{2} & : \text { Lingkungan Kerja }\end{array}$

Untuk mengetahui besar pengaruh dari variabel variabel secara jelas. Jika nilai $F$ hitung < F-tabel atau nilai signifikansi $\mathrm{F}$ > 0,05, maka $\mathrm{H} 0$ diterima artinya tidak ada pengaruh secara simultan variabel $\left(\mathrm{X}_{1}, \mathrm{X}_{2}, \mathrm{X}_{3}\right)$ terhadap variabel dependen (Y) (Sugiyono, 2012).

$$
\mathbf{R}^{2}=(\mathbf{r})^{2} \times 100 \%
$$

Keterangan :

$\begin{array}{ll}\mathrm{R}^{2} & =\text { Koefesien Determinasi } \\ \mathrm{r} & =\text { Koefesien Korelasi }\end{array}$

Untuk mengetahui apakah variabel variabel independen berpengaruh signifikan terhadap variabel dependen maka dilakukan pengujian dengan menggunakan uji t. Pengukuran derajat signifikan yang dipakai adalah 0,05 (Sugiyono, 2012).

$$
t=\frac{\bar{X}-\mu}{\left\{\frac{S D}{\sqrt{N}}\right\}}
$$

Keterangan :

$$
\begin{array}{ll}
\mathrm{t} & : \text { Nilai Hitung } \\
\bar{X} & : \text { Rata-Rata Sampel } \\
\mu & : \text { Nilai parameter } \\
S D & : \text { Standar deviasi sampel } \\
N & : \text { Jumlah Sampel }
\end{array}
$$

Jika $\mathrm{t}$ hitung $<\mathrm{t}$ tabel : H0 ditolak secara signifikan

Artinya :

a. Terdapat pengaruh yang signifikan dari variabel Komunikasi terhadap kinerja karyawan pada PT. PLN Cabang Banjarmasin.

b. Terdapat pengaruh yang signifikan dari variabel lingkungan kerja terhadap kinerja karyawan pada PT. BESS Finance Banjarmasin

Uji $\mathrm{F}$ dilakukan Untuk mengetahui apakah Komunikasi $\left(\mathrm{X}_{1}\right)$, Lingkungan Kerja $\left(\mathrm{X}_{2}\right)$ dan secara simultan berpengaruh terhadap Kinerja Karyawan (Y).

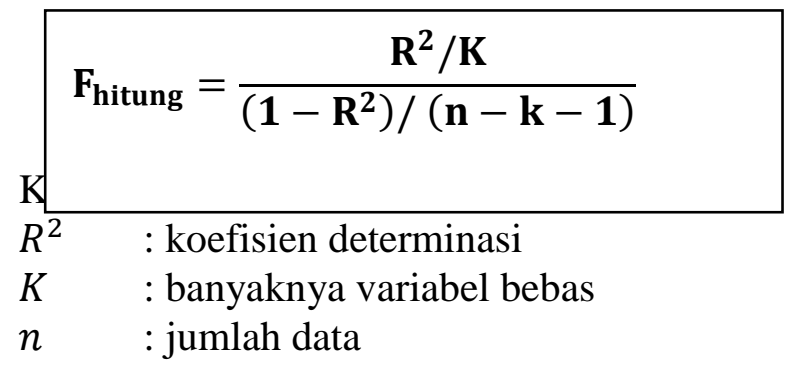

Jika nilai $\mathrm{F}$ hitung $<\mathrm{F}$ - tabel atau nilai signifikansi $F>0,05$ maka $\mathrm{H} 0$ diterima artinya tidak ada pengaruh secara bersamasama (simultan) variabel independen $\left(\mathrm{X}_{1}, \mathrm{X}_{2}\right.$ dan $\mathrm{X}_{3}$ ) terhadap variabel dependen $(\mathrm{Y})$

Jika nilai Fhitung < F- tabel atau nilai signifikansi $\mathrm{F}<0,05$ maka $\mathrm{H} 0$ ditolak artinya ada pengaruh secara bersama-sama (simultan) variabel independen $\left(\mathrm{X}_{1}, \mathrm{X}_{2}\right.$ dan 
$\left.\mathrm{X}_{3}\right)$ terhadap variabel dependen

(Sugiyono, 2012).

\section{HASIL DAN PEMBAHASAN \\ Hasil Uji Kualitas data Variabel \\ 1. Uji Validitas}

Uji validitas digunakan untuk menguji kevalidan instrumen variabel penelitian. Untuk menguji kevalidan instrumen variabel dilakukan dengan cara mengkorelasikan butir-butir pertanyaan dengan skor total instrumen variabel. Suatu koesioner dikatakan valid jika memenuhi syarat apabila koefisien korelasi $\mathrm{r}$ hitung > 0,3 (Sugiyono : 2012) .

Berdasarkan hasil pengujian seluruh item pada variabel Komunikasi, Lingkungan Kerja dan Kinerja Karyawan dinyatakan valid sehingga dapat diteruskan untuk analisis selanjutnya.

\section{Uji Reliabilitas}

Uji reliabilitas adalah mengukur keandalan suatu instrumen, pada penelitian ini digunakan koefesien Alpha Cronbach Menyatakan bahwa nilai suatu instrumen dikatakan reliabel bila nilai Alpha Cronbach $\geq 0.6$.

Berdasarkan hasil perhitungan yang dilakukan untuk variabel kinerja karyawan menunjukkan hasil yang baik, karena syarat syarat minimum yang harus dipenuhi agar kuesioner dikatakan reliabel adalah lebih besar dari 0,6 dapat terpenuhi, sehingga dapat disimpulkan bahwa kuesioner diakatakan reliabel.

\section{Analisis Regresi Linear Berganda}

Dari tabel 1 dibawah, maka persamaan Regresi yang terbentuk adalah sebagai berikut:
$Y=-0,519+0,115 X 1+1,059 X 2+e$

\section{Uji F}

Teknik uji $\mathrm{F}$ yang dipergunakan yaitu dengan membandingkan antara $\mathrm{F}$ hitung dengan $\mathrm{F}$ tabel, jika $\mathrm{F}$ hitung lebih besar dari $\mathrm{F}$ tabel maka keputusannya adalah Ho dan Ha diterima. Dengan tingkat keyakinan 95\% dan derajat kebebasan (k-1) (n-k) maka tabel untuk F (0,05) (4) (97) = 2,3092. Perbandingan antara $\mathrm{F}$ hitung dengan $\mathrm{F}$ tabel dapat dilihat dalam tabel 2 .

Dari tabel 2 dibawah ternyata $\mathrm{F}$ hitung lebih besar (70.060) dari F tabel $(2,3092)$, sehingga keputusannya adalah menolak $\mathrm{H}_{0}$ dan menerima $\mathrm{H}_{\mathrm{a}}$ yang artinya variabel $\mathrm{X} 1, \mathrm{X} 2$, secara bersama-sama berpengaruh pada kinerja.

\section{Uji t}

Teknik uji $\mathrm{T}$ yang dilakukan yaitu dengan melihat nilai $\mathrm{T}$ signifikan pada hasil pengolahan data melalui SPSS. Dalam penelitian ini $\alpha$ yang digunakan yaitu sebesar $5 \%$ (0,05). Keputusannya, jika nilai $\mathrm{T}$ signifikan < terhadap $\alpha$ maka H0 akan ditolak dan menerima Ha.

Berikut disajikan hasil perhitungan $\mathrm{T}$ signifikan masing-masing variabel bebas (kinerja karyawan).

Hasil pembuktian hipotesa pertama $(\mathrm{H} 1)$ yaitu keputusannya menolak H0 dan menerima $\mathrm{Ha}$ yang artinya uji $\mathrm{t}$ terhadap persamaan regresi yang diperoleh dari penelitian ini menunjukan hasil bahwa, secara bersama-sama kedua variabel komunikasi dan motivasi berpangaruh terhadap kinerja. 
Tabel 1 Hasil regresi berganda

\begin{tabular}{|c|c|c|}
\hline Variabel & $\mathbf{b}$ & Koefisien \\
\hline Constant & & -0.519 \\
\hline $\begin{array}{l}\text { Gaya Kepemimpina } \\
\text { (x1) }\end{array}$ & b1 & .115 \\
\hline Disiplin Kerja (x2) & $\mathrm{b} 2$ & .716 \\
\hline
\end{tabular}

Table 2 Hasil uji bersama (F)

\begin{tabular}{|c|c|c|}
\hline F Hitung & F Tabel & Sig. \\
\hline 70.060 & 2,3092 & 0,000 \\
\hline
\end{tabular}

Sumber: Data Primer yang sudah diolah

Tabel 3 Rangkuman Uji Signifikansi parsial (t)

\begin{tabular}{|c|c|c|c|}
\hline Variabel & $\begin{array}{c}\text { Signifikan } \\
\mathbf{t}\end{array}$ & sig & $\begin{array}{c}\mathbf{H}_{\mathbf{a}} \\
\text { diterima/ditiolak }\end{array}$ \\
\hline Komunikasi (X1) & 9.552 & 0,000 & Diterima \\
\hline Motivasi (X2) & 11.947 & 0.004 & Diterima \\
\hline \multicolumn{2}{r}{ Sumber: Data Primer yang sudah diolah } \\
\multicolumn{4}{|l}{}
\end{tabular}

Tabel 4 Koefisien Korelasi dan Determinasi

\begin{tabular}{|l|c|r|r|r|}
\hline Model & R & R Square & Adjusted R Square & Durbin-Watson \\
\hline 1 & $.638^{\mathrm{a}}$ & .407 & .402 & 2.672 \\
\hline \multicolumn{7}{|c}{ Sumber: Data Primer yang sudah diolah } \\
\hline \multicolumn{7}{|c|}{}
\end{tabular}

\section{Pembahasan hasil Uji Hipotesis penelitian}

\section{Regresi Linear Komunikasi terhadap} Kinerja.

Pada tabel 8 menunjukkan Nilai a = 5,019 dengan nilai koefisien regresi komunikasi sebesar 1,115 Adapun model persamaan regresi linear yang terbentuk adalah $\mathrm{Y}=-5,019+1,115$. $(\mathrm{X} 1)$

Dari hasil persamaan tersebut berarti apabila komunikasi ditingkatkan maka kinerja juga akan naik. Jadi apabila nilai komunikasi ditingkatkan menjadi 55 maka kinerjanya adalah sebesar 56,306.

\section{Regresi Linear Variabel Lingkungan Kerja}

Dari hasil analisis diperoleh nilai $\mathrm{a}=$ 0,519 dengan nilai koefisien regresi lingkungan kerja sebesar 1,059 Adapun model persamaan regresi linear yang terbentuk adalah $\mathrm{Y}=-0,519+1,059 .(\mathrm{X} 2)$.

Dari hasil persamaan tersebut jika lingkungan kerja ditingkatkan maka kinerja juga akan naik. Jadi apabila nilai motivasi ditingkatkan menjadi 60 maka kinerjanya adalah sebesar 57,717.

\section{Uji f Variabel Komunikasi terhadap Kinerja.}

Gaya kepemimpinan dan disiplin kerja secara bersama-sama atau serempak dihipotesiskan memiliki hubungan yang signifikan dengan kinerja karyawan pada PT. MDPU Banjarmasin.

Berdasarkan hasil analisis tabel 12 menunjukkan bahwa nilai $\mathrm{F}$ tabel sebesar 213.978 dengan taraf signifikan sebesar 0,000. Dari tabel F di dapat nilai tabel hitung untuk F0,05 $=3,60=2,76$, karena $213.978>$ 2,76 dan nilai sig $0,000<0,05$ maka Ho 
ditolak sehingga dapat disimpulkan bahwa gaya kepemimpinan secara serempak berpengaruh terhadap kinerja karyawan.

\section{Kesimpulan}

Motivasi mempunyai hubungan yang kuat terhadap kinerja dengan nilai koefisien korelasi sebesar 0,719 dan dinyatakan terdapat pengaruh yang positif dan signifikan antara motivasi secara parsial terhadap kinerja sebesar 11,947. Adapun faktor linngkungan kerja berpengaruh terhadap kinerja sebesar 51,8 \% sedangkan sisanya $48,2 \%$ dipengaruhi oleh faktor lain. Hal ini menunjukkan bahwa lingkungan kerja yang selama ini dibangun PT.PLN (Persero) dengan pengalokasikan dana anggaran 11 persen untuk kesejahteraan karyawan melalui gaji, asuransi dan fasilitas karyawan serta untuk peningkatan kualitas sumber daya manusianya sangat efektif dalam upaya peningkatan kualitas kinerja karyawannya. Hasil analisis tersebut tentunya juga mendukung teori Abraham $\mathrm{H}$ Maslow dalam teori kebutuhan yang di ungkapkannya yaitu Kebutuhan Fisiologis, Kebutuhan Keamanan, Kebutuhan Sosial, Kebutuhan Penghargaan dan Kebutuhan Aktualisasi Diri.

Komunikasi mempunyai hubungan yang kuat terhadap kinerja dengan nilai koefisien korelasi sebesar 0,638 dan dinyatakan terdapat pengaruh yang positif dan signifikan antara komunikasi secara parsial terhadap kinerja sebesar 9,552 Pengaruh faktor komunikasi terhadap kinerja sebesar 40,7 \% sedangkan sisanya 59,3 \% dipengaruhi oleh faktor lain.

Upaya komunikasi yang sekarang di bangun melalui Rapat Koordinasi (RAKOR) menunjukkan hasil yang sangat signifikan terhadap kinerja karyawan PT. PLN (Persero) Cabang Banjarmasin, hal tersebut merupakan realisasi UU No.14 Tahun 2008 tentang tuntutan publik terhadap transparansi melalui Rakor Komunikasi Tingkat regional sampai ketingkat wilayah. Dari analisis hasil tersebut juga mendukung pendapat Joseph De Vito (2004) tentang efektivitas komunikasi interpersonal.

Komunikasi, motivasi pengaruh yang kuat terhadap kinerja dengan nilai koefisien sebesar 0,785, dan dinyatakan terdapat pengaruh yang positif dan signifikan antara komunikasi, motivasi secara simultan terhadap kinerja sebesar 70,060. Dengan demikian pengaruh faktor komunikasi, motivasi secara silmutan terhadap kinerja berpengaruh sebesar $61,6 \%$ sedangkan sisanya $38,4 \%$ dipengaruhi oleh faktor faktor lain

\section{DAFTAR PUSTAKA}

Prof. Dr. H. Edy Sutrisno,M.Si, 2012. "Manajemen Sumber Daya manusia", Kencana Prenada Media Group.

Hadi Sutrisno, 2001. "Statistik".Yogyakarta.

Prof Dr. Yuyun Wirasasmita, M.Sc, 2006.

"Komunikasi Bisnis dan

Profesionalisme", Cetakan ke-8 PT. Remaja Rosdakarya Bandung.

Prof. Dr. Sugiyono, 2012. "Metode Penelitian Administrasi". Cetakan ke20, Akfabeta Bandung.

Dr. Ulber Silalahi, MA, 2011. "Asas Asas Manajemen". PT. refika Aditama.

Siagian Sondang P, 2003 Manajemen Sumber Daya Manusia. Jakarta: Bumi Aksara.

Prof. Dr. H. Dadan Kahmad,M.S, 2012. Manajemen Organisasi.

Mangkunegara Anwar Prabu, 2005. "Manajemen Sumber Daya Manusia Perusahaan". Cetakan Keenam. Bandung: Remaja Rosda Karya.

Pace, R. Wayne, Don F. Faules, 2005. Komunikasi Organisasi: Strategi Meningkatkan Kinerja Perusahaan. Editor Deddy Mulyana. Bandung: Remaja Rosda Karya. 
Mashul Akbar Sukamto, Masjaya, M. Gunthar Riady, 2013. "Pengaruh Lingkungan Kerja Fisik dan Non Fisik Terhadap Kinerja Pegawai Pada Badan Ketahanan Pangan dan Pelaksana Penyuluhan Daerah Kota Samarinda", e journal Administrative reform.

C. Trihendradi, 2011. "Langkah Mudah Melakukan Analisis statistik menggunakan SPSS 19".

Brahmasari Ida Ayu dan Agus Suprayetno, 2008. "Pengaruh Motivasi Kerja, Kepemimpinan dan Budaya Organisasi Terhadap Kepuasan Kerja Karyawan serta Dampaknya pada Kinerja Perusahaan (Studi kasus pada PT. Pei Hai International Wiratama Indonesia)". Jurnal Pasca Sarjana Manajemen dan Kewirausahaan. Vol.10, No. 2. Universitas 17 AgustusSurabaya.

Mathis, L. Robert, 2001. "Manajemen Sumber Daya Manusia". Jakarta: PT Salemba Empat Patria.

Sugiyono, 2002. "Statistik Penelitian". Bandung: Alfabeta.

Arif Sehfudin, 2011. "Pengaruh Gaya Kepemimpinan, Komunikasi Organisasi dan Motivasi Kerja Terhadap Kinerja (Studi Pada PT Bank Tabungan Pensiunan Nasional Cabang Semarang)". Semarang.

Ferdinand, Augusty, 2006. "Metode Penelitian Manajemen : Pedoman Penelitian Untuk Penulisan Skripsi, Tesis, dan Disertasi Ilmu Manajemen", BP Undip, Semarang.

Herlin Susilaningtyas, 2011. "Pengaruh Motivasi, Kemampuan Dan Kompensasi Terhadap Kinerja Pegawai Di Dinas Kehutanan Provinsi Jawa Timur". Tesis Universitas Pembangunan Nasional, Surabaya.

Gomes, Faustino, Cardoso, 2001. "Manajemen Sumber Daya Manusia". Andi Offset, Yogyakarta.

Suparman, 2007. "Pengaruh Peran Kepemimpinan, Motivasi Dan Komitmen Organisasi Terhadap Kepuasan Kerja Dalam Meningkatkan”. Tesis Universitas Diponegoro,
Semarang.

Kistoyo, 2008. "Pengaruh Kepemimpinan, Komunikasi Dan Lingkungan Fisik Terhadap Kinerja Pegawai Pada Kantor Dinas Pendidikan Kabupaten Pekalongan", Tesis Universitas Sebelas Maret Surakarta.

Bambang Tri Cahyono, 2001. "Manajemen Sumber Daya Manusia".. Ghalia. Jakarta.

Melayu Hasibuan SP, 1994. Manajemen Sumber Daya Manusia. Mas Agung. Jakarta.

Eva Kris Diana Devi, 2009. "Analisis Pengaruh Kepuasan Kerja Dan Motivasi Terhadap Kinerja Karyawan Dengan Komitmen Organisasional Sebagai Variabel Intervening ( Studi Pada Karyawan Outsourcing Pt Semeru Karya Buana Semarang )".Tesis Universitas Diponegoro Semarang.

M. Isa Indrawan, 2009. "Pengaruh Kompetensi Komunikasi Dan Gaya Kepemimpinan Sumber Daya Manusia Terhadap Kinerja SDM". Jurnal Ilmiah Abdi Ilmu Vol. 2 No. 1. ISSN : 1979 5408.

Prawirosentono S., 2000. "Kebijakan Kinerja Karyawan”. Yogyakarta. BPFE.

Ruky. A., 2001, Sistem Manajemen Kinerja, Jakarta Gramedia.

Barcal R, 2001. "Manajemen Sumber Daya Manusia". Jakarta. Erlangga.

Richard L. Daft, 2010, “Manajemen” Jakarta Salemba Empat

James A. F Stoner dan Charles Wankel, 1986, "Manajemen” Jakarta Intermedia 